\title{
The Influence of Corporate Social Relations on the Stability of Strategic Alliances
}

\author{
Zhanfeng Meng Zhan Wang* Jiali Sun \\ School of Economics and Management, Shanxi University, No.92, Wucheng Road, Taiyuan City, Taiyuan \\ 030006, China
}

\begin{abstract}
Our study aims to verify the effects of social relations, opportunistic behavior and trust among partners on the stability of strategic alliance. In order to test the hypotheses, 221 valid questionnaires collected from top managers of 50 strategic alliances in China. Moreover, the results also indicate that contractual governance can moderate the influence of high-level social relations on opportunistic behavior and trust between partners. It is found that the social relationship of senior managers cannot directly affect the stability of the alliance but can negatively affect the opportunistic behavior and positively affect the trust between partners. Opportunistic behavior and trust among alliance partners affect the stability of strategic alliance negatively and positively, respectively. Contract governance can enhance the influence of senior managers' social relationships on opportunistic behavior. In addition, contract governance shows the inverted U-shaped moderating effects on the relationship between senior managers' social relations and trust.
\end{abstract}

Keywords: social relations, alliance stability, opportunistic behaviour, trust, contract governance

DOI: $10.7176 / \mathrm{EJBM} / 12-6-11$

Publication date: February $29^{\text {th }} 2020$

\section{Introduction}

With the development of modern science and technology, the competition mode of product market gradually changes from single mode to multiple modes. In this situation, the product renewal speed is accelerating day by day, the market competition is more intense, and it is difficult for enterprises to stand on their own strength in the market. Therefore, as a new form of modern organization, strategic alliance has been attracted more and more attentions by enterprises. The cooperative activities characterized by commitment and trust carried out by partners in the strategic alliance to achieve strategic goals such as resource sharing and complementary advantages, including exclusive purchase agreement, exclusive cooperative production, sharing of technical achievements, $R \& D$ cooperation agreement and joint marketing (Jorde 1990). The strategic alliance can bring practical benefits to the enterprise, including the sharing of enterprise technology so as to achieve the enterprise goals better, to achieve more effective development, at the same time, strategic alliances can enhance the ability of enterprises to access resources through sharing resources. By taking risks together to reduce the risk of a single enterprise, enterprises with relatively weak self-reliance can quickly enter the market and adapt to the market. The Cainiao Post Station in China's express industry is a typical successful case of strategic alliance. Several major express companies in China used to develop independently. There is no uniform regulation and standard for workflow and packaging style, which leads to a great waste of resources and costs. The formation of rookie express station has brought several major express companies in China together and formulated common industry standards, workflow and service mode. The express companies in the rookie post station use uniform barcode, uniform packaging and sharing technology to establish channels together. According to statistics, the total cost saved by Cainiao post station for China's express industry each year can reach 1 billion yuan. Of course, not all strategic alliances can bring benefits to enterprises. In practice, there are many unstable factors in strategic alliances, and many strategic alliances eventually fail. The existing research shows that there are high instability and high failure rate in different types, regions and countries (references). The results of KPMG survey show that the failure rate of strategic alliance is as high as 60\% (Draulans 2003). Harrigan (2010) has investigated more than 800 enterprises and found that only $14 \%$ of them have cooperated for more than 10 years, and only $40 \%$ have cooperated for more than 4 years, among which $30 \%-60 \%$ of them are unstable. The failure rate caused by the instability of strategic alliance is always high. Many empirical studies show that the instability rate of strategic alliance is as high as $30 \%-50 \%$ when the instability of alliance is defined as the liquidation, merger and reorganization of alliance members, Therefore, when managers are optimistic about the benefits brought by the success of the strategic alliance, it is necessary to calmly consider the reasons for the instability of the strategic alliance and take appropriate measures and strategies to alleviate it (Hamel G 1991). The Le Haha Hot Pot and fresh fruit instant fruit supermarket in Shanxi Province of China is a failed alliance case. The original strategic agreement was that fresh fruit would be the exclusive supply of high-quality fruit for Le Haha Hot Pot chain store. The lack of trust between the top executives of the enterprise cannot be effectively solved as soon as possible after problems occur within the alliance, on the contrary, it will make the contradiction between enterprises continue to expand, and eventually lead to the collapse of strategic alliance. For a long time, many scholars have studied the influencing factors of the 
stability of strategic alliance. Chen (2010) analyzed the factors influencing the stability of strategic alliance from the aspects of external factors and the relationship between enterprises in the alliance, using Analytic hierarchy process and weight quantification, it is found that innovation ability, core competitiveness and consistent strategic objectives are the key factors that affect the stability of competitive strategic alliance. Based on the Shapley value method, Huang (2013) studies the benefit distribution of international strategic alliance. The results show that the rationality of benefit distribution among enterprises is the key to the stability of the alliance, indicating a positive correlation between the duration of the alliance. Simonin (2015) takes 147 multinational companies as samples to explore the impact of asset specificity, corporate culture differences and organizational distance on alliance stability, and finds that asset specificity, corporate culture differences and organizational distance have a significant impact on the duration of the alliance. In addition, there are many scholars from the partner matching degree (Park 1997), policy environment (Zhang 2004), alliance scale (Niedergassel 2011) and other enterprise macro level to consider. Based on data of 203 Spanish companies, Virginia et al (2016) study the relationship between CEO's external social network, strategic flexibility and organizational performance, the results show that CEO weak social network has a positive impact on strategic flexibility, and weak social network has a significant impact on organizational performance. Cai et al (2017) take the data of 421 private enterprises listed on 421 Ashare small and medium-sized boards from 2005 to 2014 as samples, to study the impact of private entrepreneurs' political relations on mergers and acquisitions. It is found that the deeper the political relationship between entrepreneurs is, the stronger the political relationship is. For this, enterprises are more likely to carry out mergers and acquisitions. Corporate executives' social relationship is an important resource for business operation and development. The social relationship of executives will affect the acquisition of knowledge, technology, capital and other resources in enterprises and strategic alliances, Thus, it is beneficial to the development of enterprises and strategic alliances. On the contrary, due to the existence of the orientation of social relations, in the process of strategic decision-making and resource allocation, the senior managers of enterprises. It will give priority to the more closely related enterprises in the alliance, which will affect the stability of the alliance.

Based on the existing research findings, from the individual micro level, there are many factors that affect the strategic decision-making of the senior management team, including the entrepreneur's personality, education level and the social relationship of senior executives. Among them, corporate executives' social relations have a great influence on corporate strategic decision-making. Yang et al (2009) took entrepreneurs of new ventures as research objects, indicating that the social relationship intensity of entrepreneurs has an impact on resource acquisition, the stronger the relationship, the faster the access to entrepreneurial resources. Qiao et al. (2013) uses 1079 senior executives of 145 state-owned listed companies in four industries. make an empirical analysis of the relationship between senior managers' social relations and organizational financial performance. The results show that the external social network contact intensity of executives has a positive impact on business and investment performance. There are many studies on the social relations of entrepreneurs in the existing literature, which can be seen that the social relations of senior managers play a very important role in the development and management of enterprises. However, there are few studies on the relationship between social relations and the stability of strategic alliance, under the current social environment in China, social relations have a particularly important impact on the stability of business operations and strategic alliances, "Human relationship" plays an important role in management and business activities. Under the background that strategic alliance is becoming more and more important, it is of great significance to study the relationship between the social relation of entrepreneurs and the stability of strategic alliance. In this paper, from the perspective of the micro level of corporate executives' social relations, it makes up for the lack of research from the macro level and provides a new perspective for the study of the stability of strategic alliance. We have better established the connection between individual social relations at the micro level and the stability of strategic alliances at the macro level, which broadens the research field of vision. We also include the social path, opportunistic behavior, research on the correlation of trust among partners and stability of strategic alliance. On this basis, the adjustment variable of contract governance is added. Furthermore, we analyze the moderating role of contract governance in the impact of executive social relations on opportunistic behavior and trust among partners, which further reveals the influence path of the social relations of the executives on the stability of the strategic alliance.

\section{Research Hypotheses}

\subsection{The direct influence of corporate executives' social relations on the stability of strategic alliance}

Duysters and Lemmens (2003) indicate the role of social relations in the formation of strategic technology alliances. Their study reveals that when enterprises in social system establish alliances, enterprises often value the direct or indirect connection between partners and then choose partners through existing ties, or search for trustworthy enterprises in the local region, instead of actively looking for partners other than direct or indirect relationships. Yang and Zhu (2017) examine the impact of social relations among business managers on the formation of strategic alliances. The social relations of enterprise managers is the key to the formation of the alliance. Enterprises with strong connections between managers are more likely to form alliances, and these social relations have an impact 
on the formation of the alliance and the existing alliance network. That is to say, good social relations contribute to the formation of strategic alliances. In addition, social relations can promote information exchange at the enterprise level and maintain the stability of existing alliances. Yang (2009) believes that a better business friendship between executives can promote exchanges between executives and improve their sense of identity, thus it is conducive to the stable development of the strategic alliance. Li et al (2008) divided the partners into "acquaintances" and "strangers" according to the number of previous cooperation. It is believed that the familiarity of alliance members will have an impact on the development of the alliance. From the above research, social relations will have a certain impact on the stability of the alliance. Based on this, the following assumptions are proposed:

H1: Corporate executives' social relations have a positive impact on the stability of strategic alliance.

\subsection{The mediating role of opportunistic behavior and trust}

2.2.1 The mediating role of opportunism

Barney et al. (1994) believed that if there was a strong social relationship between partners, the role of contract would be weakened. Opportunism is less likely to occur in a strong social relationship, because both of them are trustworthy. Wuyts and Geyskens (2005) indicate that choosing a close partner, to some extent, can prevent opportunistic behavior. The closer the relationship between the executives in the alliance, the more channels and the higher the quality of information exchange. Moreover, due to the information asymmetry, the problems of alliance members can be reduced. Based on this, the following hypotheses $\mathrm{H} 2$ and $\mathrm{H} 3$ are proposed:

H2: Corporate executives' social relations negatively affect opportunistic behavior.

H3: Opportunistic behavior negatively affects the stability of strategic alliance.

\subsubsection{The mediating role of trust}

Trust among alliance partners is an important factor affecting the stable development of the alliance, and the trust between alliance partners has a certain connection with the social relationship of senior managers. Zhu and Qi (2016) reveal that the strength of member relationship has a positive impact on trust between partners. Crssar et al (2011) use experimental research methods to study the impact of interpersonal relationships on trust between partners in social networks. The results show that trust level is affected by the relationship between the two sides. Das and Teng (2000) believe that the trust relationship between partners is an important foundation and premise for the success of the strategic alliance, and trust is regarded as the most important factor affecting the performance of the alliance. Trusted alliance members tend to use resources for long-term development rather than for immediate interests and it is conducive to the stable development of the strategic alliance. Therefore, $\mathrm{H} 4$ and $\mathrm{H} 5$ hypotheses are proposed:

H4: Corporate executives' social relations positively affect trust among partners.

H5: Trust among partners positively affect the stability of strategic alliance.

\subsection{The moderating role of contractual governance}

To a certain extent, contractual governance helps to enhance the inhibition of senior managers' social relations on opportunistic behavior. Due to the limited rationality of human beings, the social relations among executives can reduce the possibility of opportunistic behavior. And because of information asymmetry, self-interest and other problems, opportunism will also come into being. Contractual governance as a formal way of governance that embedded in the social network, can better moderate the behavior of partners, and effectively reduce the possibility of opportunistic behavior. Contract governance can adjust the influence of senior managers' social relations on opportunism. Wu et al (2009) believe that the contract helps to reduce the conflict of interest of cooperative members, increase the exchange of knowledge among organizations, and reduce opportunistic behavior. Therefore, it helps to improve the efficiency of cooperation. In addition, contract governance can adjust the influence of senior managers' social relationship on trust between partners to a certain extent. Contractual governance is a formal management mechanism and a substitute for social relations such as kinship, which can expand the scope of relations to a certain extent. Relevant research shows that contract governance can also affect trust among partners, and contracts can increase trust among partners whether the participants are close or not. However, some scholars have put forward different views on the trust relationship between contracts and partners. For example, as Faems et al (2008) demonstrate, contracts trigger different types of trust dynamics in the alliance. Excessive contracts can reduce the trust of partners, and appropriate contracts can have a positive impact on trust. The following H6 and H7 hypotheses are proposed:

H6: Contractual governance enhances the impact of corporate executives' social relations on opportunistic behavior.

H7: There is an inverted U-shape moderating effects of contract governance on the relationship between executives' social relations and trust. 


\section{Research Design}

\subsection{Questionnaire design}

In this study, a large number of related studies were combed before the design of questionnaire questions, and the research methods and measurement scales of related variables were used for reference. At the same time, with the help of several doctoral supervisors and doctors, we discussed and revised the questionnaire questions, modified some logical questions in the questionnaire, and improved them; After that, the questionnaire was distributed in a small range, and the final correction was made according to the actual results.

The questionnaire consists of two parts: The first part includes the individual situation and the enterprise situation of the respondents, including the sample's gender, age, education background and the time of holding the post of senior manager, the enterprise situation includes the nature of the sample's enterprise, the enterprise's duration, the enterprise scale, etc. Through the analysis of the basic situation of the respondents, we can grasp the basic situation and enterprise situation of the respondents, which is conducive to the preliminary judgment of the validity of the questionnaire. The second part is the main part of the questionnaire, which consists of the variable measurement scale, including the social relationship scale, opportunistic behavior scale, trust scale among partners, contract governance scale and alliance stability scale.

\subsection{Gauge design}

3.2.1 Measurement of corporate executives' social relations

Granovetter (1973) believes that the strength of social relations can be reflected in the increase of communication time, emotional input, closeness and frequency of interaction. This study measures the strength of social relations between executives from two aspects, see Table 1:

Table 1. Measurement topics of senior managers' social relations

\begin{tabular}{|l|l|}
\hline \multicolumn{1}{|c|}{ Variable } & Measurement questions \\
\hline Executives & Often attend events with alliance partner executives. \\
\hline Social relations & Often communicate via we-chat, phone or e-mail. \\
\hline
\end{tabular}

\subsubsection{Measurement of Opportunistic behavior}

Referring to the research of foreign scholars Wallenburg and Schaffler (2014), as shown in Table 2, this paper uses three items about opportunistic behavior, including violation of agreement, doing something beneficial to oneself and the completion of previous commitments.

Table 2. Measurement of Opportunistic Behavior

\begin{tabular}{|l|l|}
\hline \multicolumn{1}{|c|}{ Variable } & \multicolumn{1}{c|}{ Measurement questions } \\
\hline \multirow{4}{*}{$\begin{array}{l}\text { Opportunistic } \\
\text { behavior }\end{array}$} & $\begin{array}{l}\text { Partners sometimes violate agreements to achieve their own } \\
\text { interests. }\end{array}$ \\
\cline { 2 - 3 } & Partners will do anything to benefit them. \\
\cline { 2 - 2 } & $\begin{array}{l}\text { Some things that the partners did not fulfill their previous } \\
\text { commitments. }\end{array}$ \\
\hline
\end{tabular}

\subsubsection{Measurement of trust between alliance partners}

The scale of trust among alliance partners is based on the research of Liu et al (2008). Liu and Tao (2007). The scale is designed from three aspects: trust in the other party's ability to achieve goals, trust in the other party's consideration of our interests and trust in the other party's cooperation attitude. As shown in Table 3:

Table 3. Trust Measurement Topics

\begin{tabular}{|c|l|}
\hline Variable & \multicolumn{1}{|c|}{ Measurement questions } \\
\hline \multirow{3}{*}{$\begin{array}{c}\text { Trust between } \\
\text { partners }\end{array}$} & Work with alliance partners to achieve goals. \\
\cline { 2 - 2 } & $\begin{array}{l}\text { Alliance partners will consider our interests when making decisions } \\
\text { involving interests. }\end{array}$ \\
\cline { 2 - 2 } & Alliance partners are sincere to us. \\
\hline
\end{tabular}

\subsection{Sample source and characteristics}

Through email, e-questionnaire and interview, this paper investigates the managers of 50 enterprises joining the strategic alliance, including Yuantong express, SF express, Youku and Alibaba. A total of 327 questionnaires were collected, 106 of which were filled in by the grass-roots employees and 106 of which were incomplete. 221 valid questionnaires were obtained, with an effective rate of $68.8 \%$. See Table 4. 
Table 4. Basic Information of Survey Sample

\begin{tabular}{|c|c|c|c|}
\hline $\begin{array}{c}\text { Essential } \\
\text { information }\end{array}$ & Project & $\begin{array}{c}\text { Sample } \\
\text { size }\end{array}$ & Percentage \\
\hline \multirow{3}{*}{$\begin{array}{l}\text { Nature of } \\
\text { enterprise }\end{array}$} & State-owned enterprise & 47 & $21.3 \%$ \\
\hline & Private enterprise & 123 & $55.7 \%$ \\
\hline & $\begin{array}{l}\text { Three foreign-funded enterprises (Sino foreign joint ventures, } \\
\text { Sino foreign cooperative ventures, foreign-funded enterprises) }\end{array}$ & 51 & $23.1 \%$ \\
\hline \multirow{4}{*}{ Enterprise scale } & Below 100 people & 63 & $28.5 \%$ \\
\hline & $100-500$ person & 69 & $31.2 \%$ \\
\hline & $500-1000$ person & 33 & $14.9 \%$ \\
\hline & Over 1000 people & 56 & $25.3 \%$ \\
\hline \multirow{3}{*}{$\begin{array}{l}\text { Duration of } \\
\text { enterprise }\end{array}$} & 3 years and less & 39 & $17.6 \%$ \\
\hline & $3-7$ years & 95 & $43.0 \%$ \\
\hline & 7 years and above & 87 & $39.4 \%$ \\
\hline \multirow{2}{*}{ Sex } & Male & 166 & $75.1 \%$ \\
\hline & female & 55 & $24.9 \%$ \\
\hline \multirow{6}{*}{ Age } & 25 and under & 0 & 0 \\
\hline & $26-30$ years old & 6 & $2.7 \%$ \\
\hline & $30-40$ years old & 87 & $39.4 \%$ \\
\hline & $41-50$ years old & 83 & $37.6 \%$ \\
\hline & $51-60$ years old & 31 & $14.0 \%$ \\
\hline & Over 60 years old & 14 & $6.3 \%$ \\
\hline \multirow{4}{*}{ Education } & Undergraduate & 126 & $57.0 \%$ \\
\hline & Master student & 52 & $23.5 \%$ \\
\hline & Doctoral students & 30 & $13.6 \%$ \\
\hline & Junior college and below & 13 & $5.9 \%$ \\
\hline \multirow{3}{*}{$\begin{array}{l}\text { Time as an } \\
\text { executive }\end{array}$} & 3 years and less & 65 & $29.4 \%$ \\
\hline & $3-6$ years & 77 & $34.8 \%$ \\
\hline & 6 years and above & 79 & $35.7 \%$ \\
\hline
\end{tabular}

\section{Data Analysis and Result Discussion}

\subsection{Reliability and validity test}

4.1.1 Reliability test

The reliability of the questionnaire is analyzed by applying the $\alpha$ reliability coefficient method to test the reliability. Spss21.0 was used to test the reliability of each variable. The results are shown in Table 5 below, which shows that all the indexes in this paper have good reliability.

Table 5. Reliability Analysis

\begin{tabular}{|c|c|c|}
\hline Variable & Cronbach $\alpha$ & Item number \\
\hline Executive social relations & 0.819 & 3 \\
\hline Contract governance & 0.863 & 4 \\
\hline Opportunistic behavior & 0.846 & 3 \\
\hline Trust between partners & 0.796 & 3 \\
\hline Alliance stability & 0.801 & 3 \\
\hline
\end{tabular}

4.1.2 Validity test

(1) KMO test and Bartlett spherical test

Firstly, KMO test and Bartlett spherical test are used to test the data. Generally, when KMO value is greater than 0.7 and Bartlett test is significant, factor analysis is suitable. KMO value of the data is 0.859 , Bartlett's test chi square value is 1662.536 , and the significance is 0.000 . According to the test results, it is concluded that the construction validity of this paper is good and the data is suitable for the next step of factor analysis.

(2) Exploratory factor analysis

The orthogonal rotation method is used to rotate the factors, and the total variance table is explained as shown in Table 6 below. According to the datum with eigenvalue greater than 1, five common factors are extracted from the results, and the eigenvalues of the five common factors are $6.009,1.967,1.552,1.179$ and 1.033 , and $37.557 \%$, $12.293 \%, 9.703 \%, 7.366 \%$ and $6.453 \%$ of the total variance were explained respectively, and the contribution rates were $37.557 \%, 49.850 \%, 59.553 \%, 66.919 \%$ and $73.372 \%$ respectively. Generally, if the cumulative contribution rate is more than $60 \%$, it is considered that the extracted factors have better explanatory ability to each variable. The cumulative contribution rate of this paper is $73.372 \%$. According to the results, it can be judged that the 
extracted 5 common factors can explain the information contained in the 16 original items.

In table 7, the load value of each main component corresponding item after the rotation of 16 items is greater than 0.5 , and the rotated item can correspond to the assumed dimension one by one, indicating that the paper has good construct validity.

Table 6. Total Variance of Interpretation

\begin{tabular}{|c|c|c|c|c|c|c|c|c|c|}
\hline & \multicolumn{3}{|c|}{ Initial eigenvalue } & \multicolumn{2}{|c|}{ Extract the sum of load squares } & \multicolumn{2}{|c|}{ Sum of squares of rotating loads } \\
\cline { 2 - 11 } & Total & Variance\% & Cumula-tive \% & Total & Variance\% & Cumula-tive \% & Total & Variance\% & Cumula-tive \% \\
\hline 1 & 6.009 & 37.557 & 37.557 & 6.009 & 37.557 & 37.557 & 2.903 & 18.146 & 18.146 \\
\hline 2 & 1.967 & 12.293 & 49.850 & 1.967 & 12.293 & 49.850 & 2.285 & 14.279 & 32.425 \\
\hline 3 & 1.552 & 9.703 & 59.553 & 1.552 & 9.703 & 59.553 & 2.213 & 13.830 & 46.255 \\
\hline 4 & 1.179 & 7.366 & 66.919 & 1.179 & 7.366 & 66.919 & 2.180 & 13.622 & 59.877 \\
\hline 5 & 1.033 & 6.453 & 73.372 & 1.033 & 6.453 & 73.372 & 2.159 & 13.495 & 73.372 \\
\hline 6 & .589 & 3.681 & 77.053 & & & & & & \\
\hline 7 & .503 & 3.141 & 80.194 & & & & & & \\
\hline 8 & .495 & 3.093 & 83.288 & & & & & & \\
\hline 9 & .460 & 2.872 & 86.160 & & & & & & \\
\hline 10 & .392 & 2.449 & 88.609 & & & & & & \\
\hline 11 & .368 & 2.301 & 90.909 & & & & & & \\
\hline 12 & .345 & 2.154 & 93.064 & & & & & & \\
\hline 13 & .329 & 2.056 & 95.120 & & & & & & \\
\hline 14 & .294 & 1.838 & 96.958 & & & & & & \\
\hline 15 & .277 & 1.730 & 98.688 & & & & & & \\
\hline 16 & .210 & 1.312 & 100.000 & & & & & & \\
\hline
\end{tabular}

Table 7. Composition Matrix after Rotation

\begin{tabular}{|l|c|c|c|c|c|}
\hline \multirow{2}{*}{} & \multicolumn{5}{|c|}{ Component } \\
\cline { 2 - 6 } & 1 & 2 & 3 & 4 & 5 \\
\hline Contract governance 1 & .857 & & & & \\
\hline Contract governance 3 & .811 & & & & \\
\hline Contract governance 2 & .811 & & & & \\
\hline Contract governance 4 & .785 & & & & \\
\hline Executive social relations 1 & & .842 & & & \\
\hline Executive social relations 2 & & .817 & & & \\
\hline Executive social relations 3 & & .805 & & & \\
\hline Opportunistic behavior 2 & & & .796 & & \\
\hline Opportunistic behavior 1 & & & .792 & & \\
\hline Opportunistic behavior 3 & & & .775 & & \\
\hline Alliance stability 2 & & & & .839 & \\
\hline Alliance stability 3 & & & & .782 & \\
\hline Alliance stability 1 & & & & .740 & \\
\hline Trust between partners 3 & & & & & .829 \\
\hline Trust between partners 2 & & & & & .792 \\
\hline Trust between partners 1 & & & & & .748 \\
\hline
\end{tabular}

(3) Test factor analysis

Because exploratory factors are not rigorous in validity analysis, for test validity more strictly, this paper uses AMOS24.0 software to carry out confirmatory factor analysis. The confirmatory factor analysis chart and fitting values are shown in Figure 1 and table 8.

The confirmatory factor analysis chart can clearly represent the dimensions measured in this paper and each item contained in each dimension.

The factor loading of the items in all dimensions are higher than 0.5, indicating that the scale has good content validity. From the perspective of differentiated validity, the aggregation of each dimension is greater than that of other dimensions, indicating that the scale has a good differentiated validity.

In the fitting value of confirmatory factor analysis, the ratio of chi square statistics to degrees of freedom $\left(\chi^{2} / \mathrm{df}\right)$ is less than 3 and with GFI, AGFI, NFI, IFI and TLI are all greater than 0.9, the RMSEA is less than 0.05, the model fits well. According to table 8. All measurement dimensions of the model are supported by good data. In conclusion, the scale has good structure validity.

The convergence validity is judged by factor load, mean variance extraction and combination reliability. See 
Table 9 below for details. From table 9, we can see that the factor loads of social relations, trust among partners, alliance stability, opportunistic behavior and contract governance are all greater than 0.6 ; The average variation extraction (AVE) was $0.603,0.587,0.587,0.649$ and 0.617 , respectively, all of which were greater than 0.5 ; The combined reliability $(\mathrm{CR})$ was $0.820,0.809,0.810,0.847$ and 0.865 , respectively, which were greater than 0.6 , indicating that the convergence validity of this study met the standard.

Table 8 Confirmatory Factor Analysis Fitting

\begin{tabular}{|c|c|c|}
\hline Test volume & Critical value & Index \\
\hline$\chi^{2} / \mathrm{df}$ & $<5$ suitable,$<3$ good & 1.119 \\
\hline GFI & $\geq 0.9$ & 0.948 \\
\hline AGFI & $\geq 0.9$ & 0.924 \\
\hline NFI & $\geq 0.9$ & 0.938 \\
\hline IFI & $\geq 0.9$ & 0.993 \\
\hline TLI & $\geq 0.9$ & 0.991 \\
\hline CFI & 0.9 & 0.993 \\
\hline RMSEA & $<0.08$ appropriate,$<0.05$ good & 0.023 \\
\hline
\end{tabular}

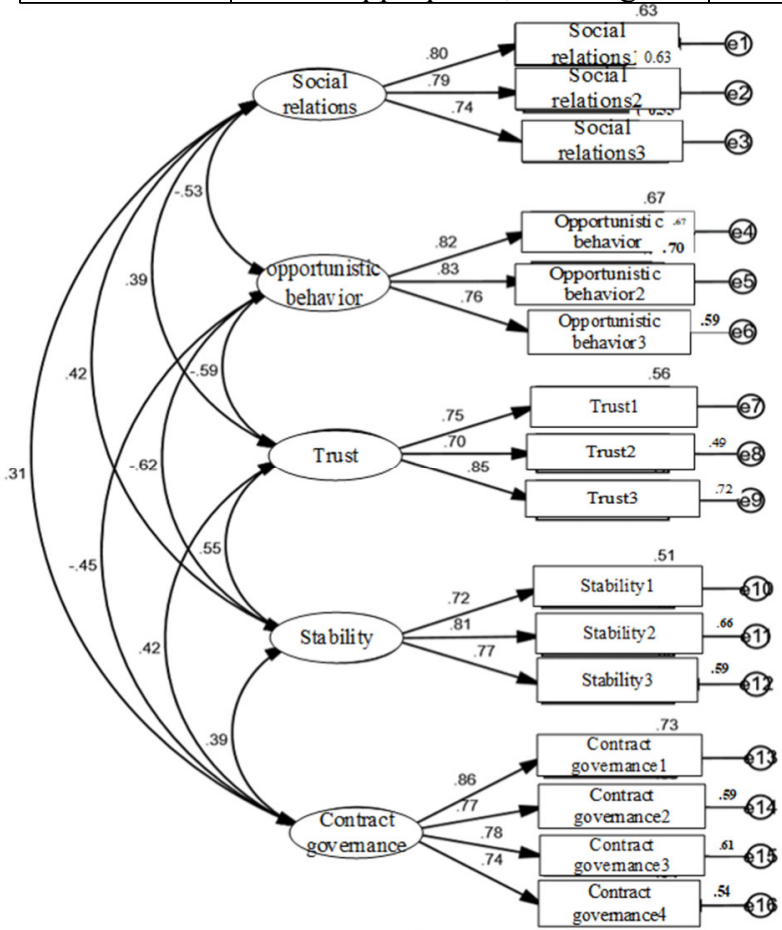

Figure 1. Confirmatory factor analysis chart Table 9. Convergence Validity

\begin{tabular}{|c|c|c|c|c|}
\hline Dimension & Item & Estimate & $\mathrm{CR}$ & AVE \\
\hline \multirow{3}{*}{$\begin{array}{l}\text { Executive social } \\
\text { relations }\end{array}$} & Executive social relations 1 & 0.795 & \multirow{3}{*}{0.820} & \multirow{3}{*}{0.603} \\
\hline & Executive social relations 2 & 0.791 & & \\
\hline & Executive social relations 3 & 0.743 & & \\
\hline \multirow{3}{*}{$\begin{array}{l}\text { Trust between } \\
\text { partners }\end{array}$} & Trust1 & 0.746 & \multirow{3}{*}{0.809} & \multirow{3}{*}{0.587} \\
\hline & Trust2 & 0.699 & & \\
\hline & Trust3 & 0.846 & & \\
\hline \multirow{3}{*}{$\begin{array}{l}\text { Alliance } \\
\text { stability }\end{array}$} & Alliance stability 1 & 0.716 & \multirow{3}{*}{0.810} & \multirow{3}{*}{0.587} \\
\hline & Alliance stability 2 & 0.814 & & \\
\hline & Alliance stability 3 & 0.766 & & \\
\hline \multirow{3}{*}{$\begin{array}{l}\text { Opportunistic } \\
\text { behavior }\end{array}$} & opportunistic behavior 1 & 0.818 & \multirow{3}{*}{0.847} & \multirow{3}{*}{0.649} \\
\hline & opportunistic behavior 2 & 0.834 & & \\
\hline & opportunistic behavior 3 & 0.763 & & \\
\hline \multirow{4}{*}{$\begin{array}{c}\text { Contract } \\
\text { governance }\end{array}$} & Contract governance 1 & 0.855 & \multirow{4}{*}{0.865} & \multirow{4}{*}{0.617} \\
\hline & Contract governance 2 & 0.767 & & \\
\hline & Contract governance 3 & 0.778 & & \\
\hline & Contract governance 4 & 0.738 & & \\
\hline
\end{tabular}




\subsection{Variable correlation analysis}

Pearson's method is used to analyze the correlation among the five variables, namely, social relationship, contractual governance, opportunistic behavior, trust among partners, and alliance stability. The correlation of variables is used to measure the correlation between the two variables. The specific correlation coefficients are shown in Table 10 below. The results showed that the correlation between the variables was significant $(\mathrm{P}<0.05)$.

Table 10. Correlation among Variables

\begin{tabular}{|c|l|l|l|l|l|}
\hline Variable & $\begin{array}{c}\text { 1.Executive } \\
\text { social relations }\end{array}$ & $\begin{array}{c}2 . \text { Contract } \\
\text { governance }\end{array}$ & $\begin{array}{c}\text { 3. Opportunistic } \\
\text { behavior }\end{array}$ & $\begin{array}{c}4 . \text { Trust between } \\
\text { partners }\end{array}$ & $\begin{array}{c}5 . \text { Alliance } \\
\text { stability }\end{array}$ \\
\hline 1. & 0.777 & & & & \\
\hline 2. & $0.261^{* *}$ & 0.766 & & & \\
\hline 3. & $-0.436^{* *}$ & $-0.397 * *$ & 0.766 & & \\
\hline 4. & $0.325^{* *}$ & $0.345^{* *}$ & $-0.499 * *$ & 0.806 & 0.786 \\
\hline 5. & $0.352^{* *}$ & $0.338^{* *}$ & $-0.523 * *$ & $0.470^{* *}$ & \\
\hline
\end{tabular}

\subsection{Hypothesis test}

4.3.1 Test of direct and mediating effects

(1) Model composition and model fitting

According to the above reliability and validity test, and the theory of structural equation model, using amos 24.0 software, we draw the structural model of senior managers' social relations to opportunistic behavior, trust between partners, alliance stability and opportunistic behavior, trust between partners to alliance stability, as shown in Figure 2. The core of structural equation model test is the fit of the model. To test the fit between the model and the observation data, it needs to judge by the fit index. The fitting index of this model is shown in Table 11.

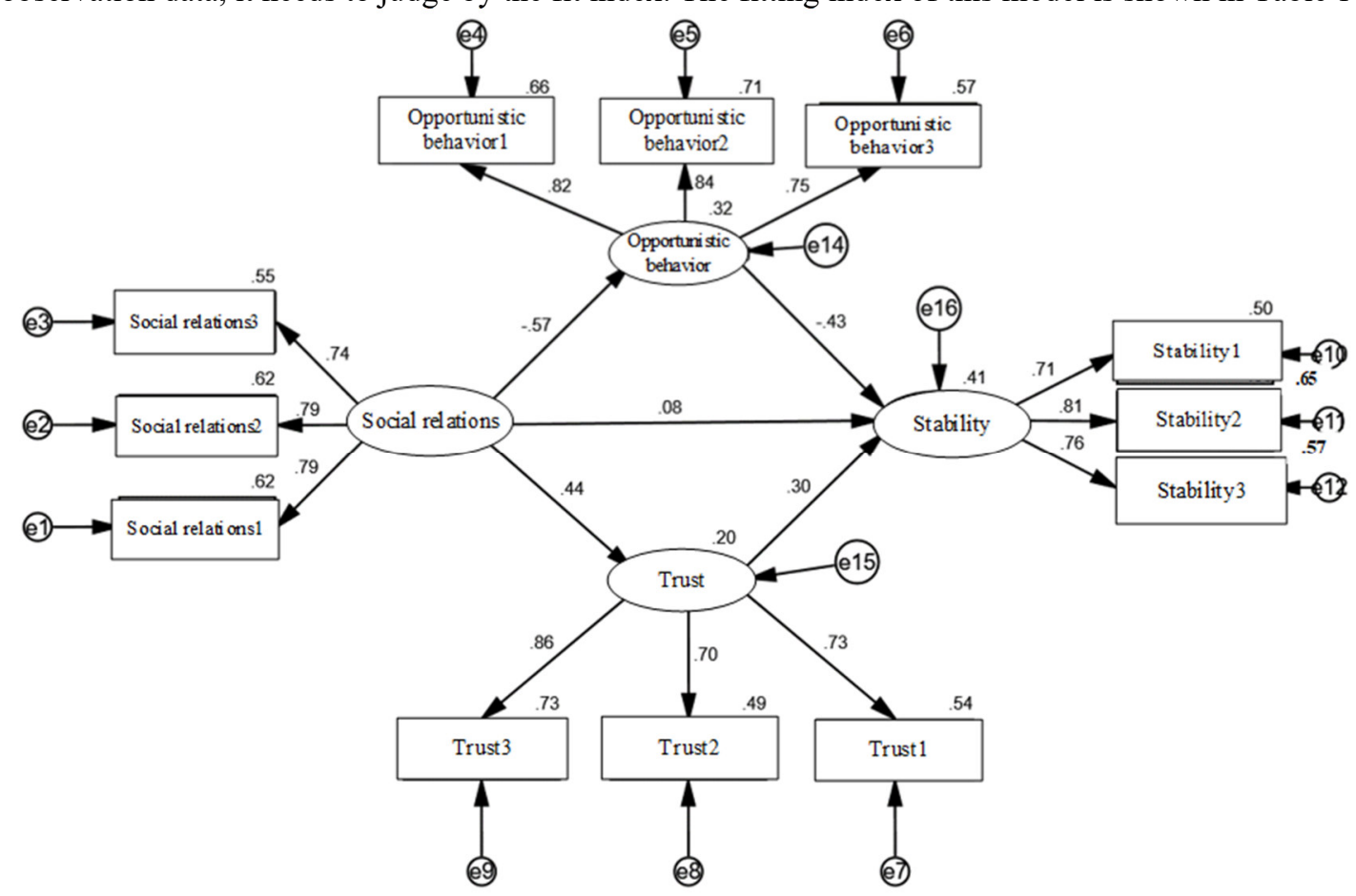

Figure 2. Structure Model

Table 11. Model Fitting

\begin{tabular}{|c|c|c|}
\hline Test volume & Critical value & Item \\
\hline$\chi^{2} / \mathrm{df}$ & $<5$ suitable, $<3$ good & 1.864 \\
\hline GFI & $\geq 0.9$ & 0.937 \\
\hline AGFI & $\geq 0.9$ & 0.900 \\
\hline NFI & $\geq 0.9$ & 0.924 \\
\hline IFI & $\geq 0.9$ & 0.963 \\
\hline TLI & $\geq 0.9$ & 0.950 \\
\hline CFI & $\geq 0.9$ & 0.963 \\
\hline RMSEA & $<0.08$ appropriate,$<0.05$ good & 0.063 \\
\hline
\end{tabular}


(2) Path coefficient and hypotheses test

In this paper, the coefficients in the model are analyzed, and the specific coefficients and hypothesis test results are shown in Table 12. The path coefficient between executive social relationship and alliance stability is 0.076 ( $\mathrm{P}$ $=0.431>0.05)$, which indicates that the influence of executive social relationship on alliance stability does not exist, and the $\mathrm{H} 1$ hypothesis does not hold. The path coefficient between the social relationship of senior managers and opportunistic behavior is $-0.565(\mathrm{P}<0.001)$, which indicates that there is a significant negative effect of the social relationship of senior managers on opportunistic behavior, and the $\mathrm{H} 2$ hypothesis holds. The path coefficient between opportunistic behavior and alliance stability is $-0.433(\mathrm{P}<0.001)$, which shows that opportunistic behavior has a significant negative impact on alliance stability, $\mathrm{H} 3$ hypothesis holds. The path coefficient between executive social relationship and trust among partners is $0.442(\mathrm{P}<0.001)$, which indicates that there is a significant positive effect of executive social relationship on trust among partners, and $\mathrm{H} 4$ hypothesis holds. The path coefficient between trust among partners and alliance stability is $0.304(\mathrm{P}<0.001)$, which indicates that trust among partners has a significant positive impact on alliance stability, and $\mathrm{H} 5$ hypothesis holds.

Table 12. Path Coefficient and Hypothesis Test

\begin{tabular}{|c|c|c|c|c|c|c|}
\hline \multicolumn{3}{|c|}{ Route } & $\begin{array}{l}\text { Standardized } \\
\text { regression coefficient }\end{array}$ & S.E. & C.R. & $\mathrm{P}$ \\
\hline $\begin{array}{l}\text { Opportunistic } \\
\text { behavior }\end{array}$ & $<-$ & $\begin{array}{l}\text { Executive social } \\
\text { relations }\end{array}$ & -0.565 & 0.088 & -6.772 & $* * *$ \\
\hline $\begin{array}{c}\text { Trust between } \\
\text { partners }\end{array}$ & $\begin{array}{l}<- \\
-\end{array}$ & $\begin{array}{c}\text { Executive social } \\
\text { relations }\end{array}$ & 0.442 & 0.091 & 5.013 & $* * *$ \\
\hline Alliance stability & $\begin{array}{l}<- \\
- \\
\end{array}$ & $\begin{array}{c}\text { Executive social } \\
\text { relations }\end{array}$ & 0.076 & 0.080 & 0.788 & 0.431 \\
\hline Alliance stability & $\begin{array}{l}<- \\
- \\
\end{array}$ & $\begin{array}{c}\text { Opportunistic } \\
\text { behavior }\end{array}$ & -0.433 & 0.080 & -4.278 & $* * *$ \\
\hline Alliance stability & $\begin{array}{l}<- \\
-\end{array}$ & $\begin{array}{c}\text { Trust between } \\
\text { partners }\end{array}$ & 0.304 & 0.073 & 3.358 & $* * *$ \\
\hline
\end{tabular}

4.3.2 Regression analysis of moderating effects

In order to test the regulatory role of contract governance in the impact of senior managers' social relations on opportunistic behavior, this paper uses the hierarchical regression method to establish multiple models for analysis, and the results are shown in Table 13. The first level includes the control variables, such as gender, age, education background, nature of the enterprise, duration, length of service of senior executives, and enterprise scale. In the second layer, we add the independent variable executive social relations. In the third layer, the regulatory variable contract governance is added, and in the fourth layer, the interaction item social relations of senior managers $\times$ contract governance is added.

Regression analysis showed that contractual governance had a moderating effect on the influence of senior managers' social relations on opportunistic behavior $(\beta=-0.242, \mathrm{P}<0.01)$. After the interaction term of social relations of senior managers $\times$ contract governance is added, the negative effect of social relations of senior managers on opportunistic behavior is enhanced. As a moderator, contract governance can positively moderate the impact of social relations of senior managers on opportunistic behavior. H6 hypothesis is verified.

Table 13. The Moderating Effect of Contract Governance in The H6 Hypothesis

\begin{tabular}{|l|l|l|l|l|}
\hline \multirow{2}{*}{ Variable } & \multicolumn{4}{|c|}{ Dependent variable: opportunistic behavior } \\
\cline { 2 - 5 } & Model 1 & Model 2 & Model 3 & Model 4 \\
\hline Control variable & & & & \\
\hline Sex & 0.001 & -0.014 & -0.024 & -0.049 \\
\hline Age & -0.022 & -0.029 & -0.003 & 0.029 \\
\hline Education & 0.075 & 0.003 & 0.011 & 0.025 \\
\hline Nature of enterprise & -0.063 & -0.028 & -0.009 & -0.030 \\
\hline Years of existence & -0.014 & -0.040 & -0.055 & -0.060 \\
\hline Duration of senior- management & 0.049 & 0.081 & 0.067 & 0.046 \\
\hline Enterprise scale & -0.058 & 0.008 & -0.020 & -0.032 \\
\hline Independent variable & & & & \\
\hline Executive social relations & & $-0.443^{* * *}$ & $-0.363^{* * *}$ & $-0.373^{* * *}$ \\
\hline Moderator variable & & & & \\
\hline Contract governance & & & $-0.304^{* * *}$ & $-0.333^{* * *}$ \\
\hline Interaction item & & & & \\
\hline Executive social relations $\times$ contractual governance & & & & $-0.242^{* * * *}$ \\
\hline R2 & 0.012 & 0.200 & 0.285 & 0.340 \\
\hline
\end{tabular}




\begin{tabular}{|l|l|l|l|l|}
\hline \multirow{2}{*}{ Variable } & \multicolumn{4}{c|}{ Dependent variable: opportunistic behavior } \\
\cline { 2 - 5 } & Model 1 & Model 2 & Model 3 & Model 4 \\
\hline$\Delta \mathrm{R} 2$ & -0.021 & 0.170 & 0.254 & 0.309 \\
\hline $\mathrm{F}$ & 0.360 & $6.631 * * *$ & $9.325^{* * *}$ & $10.836^{* * *}$ \\
\hline Notes: * for $\mathrm{p}<0.05, * *$ for $\mathrm{p}<0.01, * * *$ for $\mathrm{p}<0.001$ \\
\hline
\end{tabular}

To test the inverted U-shaped moderating effect of contract governance on the trust between executive social relations and partners, the hierarchical regression method was used to establish multiple models for analysis, and the results are shown in table 14. The first level includes the control variables, such as gender, age, education background, nature of the enterprise, duration, length of service of senior executives, and enterprise scale. In the second layer, we add the independent variable executive social relations. In the third layer, we add moderating variable contract governance, and in the fourth layer, we add interaction item social relations of senior managers $\times$ contract governance. In the fifth layer, the interactive senior managers' social relations $\times$ contractual governance parties are added. The results of regression analysis show that there is a moderating effect of contract governance on the trust between senior managers and their partners $(\beta=0.200, \mathrm{P}<0.01)$. At the same time, the moderating effect of contract governance on the square value of senior managers' social relations on trust among partners reached a significant level $(\beta=-0.324, \mathrm{P}<0.01)$, it shows that there is a quadratic function relationship between contract governance and the regulation of trust relationship between senior managers' social relations and alliance partners, and $\beta$ is negative. It shows that the opening of quadratic curve is downward, indicating that contract governance plays an inverted U-shaped role in the influence of senior managers' social relations on trust between partners. H7 hypothesis is verified.

According to the above analysis, the path map of the impact of corporate executives' social relations on the stability of strategic alliance is obtained, as shown in Figure 3.

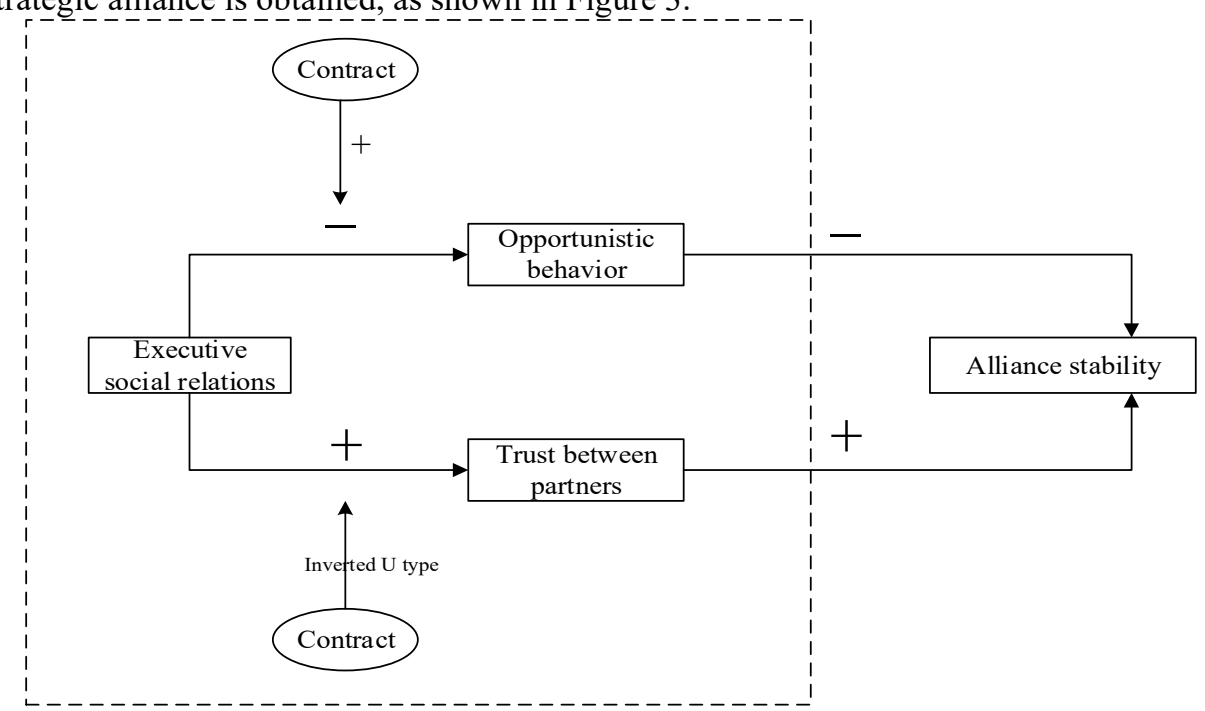

Figure 3. The Influence Path of Senior Managers' social Relations on Alliance Stability

Table 14. The Moderating Effect of Contract Governance in The H7 Hypothesis

\begin{tabular}{|l|c|c|c|c|c|}
\hline \multirow{2}{*}{ Variable } & \multicolumn{5}{c|}{ Dependent variable: Trust between partners } \\
\cline { 2 - 6 } & Model 1 & Model 2 & Model 3 & Model 4 & Model 5 \\
\hline Control variable & & & & & \\
\hline Sex & -0.151 & -0.139 & -0.130 & -0.104 & -0.135 \\
\hline Age & 0.108 & 0.113 & 0.089 & 0.056 & 0.075 \\
\hline Education & 0.032 & 0.089 & 0.082 & 0.067 & 0.062 \\
\hline Nature of enterprise & -0.068 & -0.095 & -0.113 & -0.091 & -0.092 \\
\hline Years of existence & 0.032 & 0.052 & 0.066 & 0.071 & 0.071 \\
\hline Duration of senior- management & $-0.134^{*}$ & $-0.160^{* *}$ & $-0.146^{*}$ & $-0.125^{*}$ & $-0.114^{* *}$ \\
\hline Enterprise scale & 0.014 & -0.038 & -0.012 & 0.000 & -0.013 \\
\hline Independent variable & & & & & \\
\hline Executive social relations & & $0.350^{* * *}$ & $0.276^{* * *}$ & $0.286^{* * *}$ & $0.510^{* * *}$ \\
\hline Moderator variable & & & & & \\
\hline Contract governance & & & $0.281^{* * *}$ & $0.311^{* * *}$ & $0.357^{* * *}$ \\
\hline Interaction item & & & & & \\
\hline
\end{tabular}




\begin{tabular}{|l|c|c|c|c|c|}
\hline \multicolumn{1}{|c|}{ Variable } & \multicolumn{3}{c|}{ Dependent variable: Trust between partners } \\
\cline { 2 - 6 } & Model 1 & Model 2 & Model 3 & Model 4 & Model 5 \\
\hline $\begin{array}{l}\text { Executive social relations } \times \text { contractual } \\
\text { governance }\end{array}$ & & & & $0.251^{* * *}$ & $0.200^{* *}$ \\
\hline $\begin{array}{l}\text { Executive social relations } \times \text { contractual } \\
\text { governance party }\end{array}$ & & & & & $-0.324 * *$ \\
\hline R2 & & & & & \\
\hline$\Delta$ R2 & 0.074 & 0.155 & 0.227 & 0.287 & 0.327 \\
\hline F & 0.012 & 0.123 & 0.194 & 0.253 & 0.291 \\
\hline Notes: * for $\mathrm{p}<0.05, * *$ for $\mathrm{p}<0.01, * * *$ for $\mathrm{p}<0.001$ & 2.615 & $4.844 * * *$ & $6.871^{* * *}$ & $8.447^{* * *}$ & $9.228^{* * *}$ \\
\hline
\end{tabular}

4.3.3 Discussion

Based on the above empirical analysis of the impact of entrepreneurs' social relations on the stability of strategic alliance, the results are discussed.

(1) Through data analysis, it is found that the hypothesis of "corporate executives' social relations positively affect alliance stability" is not true, and the analysis results show that corporate executives' social relations have no direct impact on alliance stability. There is no direct relationship between senior managers' social relations and alliance stability, but it needs to influence alliance stability by influencing intermediate variables. This is different from Costa's (2018) research. He believes that the stable development of the strategic alliance portfolio is influenced by the exchange efficiency of knowledge and information and the learning and exploration ability of its members. At the same time, the strong trust and reciprocity among members are also conducive to the stable development of the alliance [30]. He believes that the social relations of alliance members and the system of other elements directly affect the stability of strategic alliance. This paper argues that the social relationship of executives can not directly affect the stability of strategic alliance, but indirectly affect the stability of alliance through the change of intermediate factors.

(2) The data analysis shows that the social relationship of senior managers has a negative impact on opportunistic behavior. Wathne and Heide (2000) believe that choosing reliable partners will reduce the possibility of opportunistic behavior and reduce information asymmetry between partners to inhibit opportunistic behavior. This study believes that a good social relationship between senior executives can help to open up information block and reduce information asymmetry, which is similar to the existing research. Foreign scholar Barney (1994) believe that if there is a strong social relationship between partners, whether there are strict regulations or restrictions, there will be no opportunistic behavior between them, because good social relations between them make their cooperation more stable, and there is no opportunistic behavior. This view is consistent with this study. This study believes that the social relationship of entrepreneurs in strategic alliances has a direct impact on opportunistic behavior, good social relations are conducive to information exchange and trust building among alliance members, for reduce the occurrence of opportunistic behaviors. Good social relations can indirectly improve the stability of strategic alliance by reducing the occurrence of opportunistic behavior.

(3) The results show that opportunistic behavior has negative influence on alliance stability. Ge et al (2017) said that the formation of strategic alliances by enterprises in different industries can help enterprises to break the resource dilemma, but opportunistic behavior will reduce cooperation motivation and affect the stability of the alliance. Cui and $\mathrm{Hu}$ (2011) divide the intellectual property protection system into weak intellectual property protection system and strong intellectual property protection system based on evolutionary game, the dynamic system equation of technological innovation alliance stability based on opportunistic behavior guarantee alliance system is constructed, and the results show that the imperfect institutional environment among the members of technological innovation alliance will greatly increase the probability of opportunistic behavior, this will reduce the competitiveness and cohesion of technological innovation alliance. In this paper, the influence of opportunism on the stability of alliance is the same as that of previous studies.

(4) Corporate executives' social relationship has a positive impact on trust between partners, which means that a good social relationship between executives is conducive to the establishment of trust between alliance partners. Zhu and Qi also put forward the same view, and their research shows that the strength of member relationship has a positive impact on trust between partners. The greater the intensity of social relations among executives, the smoother the communication between enterprises, and the easier to promote the formation of trust mechanism. When Smith studied customer relationship management, he pointed out that there are good and long-term social relationships between partners. It is easy to form an economic, emotional, psychological and material dependence in the process of cooperation, which makes the partners more closely linked(Smith B 1998). This is very similar to the point of view of this study. Trust can be considered as the kind of economic, emotional, psychological and material dependence of Smith.

(5) From the results of data analysis, it is found that trust among partners has a positive impact on the stability of alliance, which means that a higher trust relationship among alliance members will be conducive to the stable 
development of strategic alliance. Ganesan (1994) believes that trust is the emotional hub in the process of business transactions and an important reason for the continuity of business relations. The higher the degree of trust, the more willing the alliance partners are to maintain the cooperative relationship between the two sides. Based on the study of Japan's strategic alliance, Cullen (2000) focused on mutual trust and commitment between partners, established a dynamic adjustment model based on trust and commitment, and found that trust can affect the performance of the alliance and the realization of the objectives of the alliance. The viewpoint of this study is consistent with the existing research. The trust relationship between partners is an indispensable factor in the development of strategic alliance. When the trust degree between alliance members is high, the communication obstacle of information between alliance members is reduced. Alliance members will consider the overall interests of the alliance while considering their own interests and pay more attention to the development of the alliance. Alliance members are more willing to solve the problems in the alliance together to ensure the stable development of the alliance.

(6) Contractual governance enhances the impact of corporate executives' social relations on opportunistic behavior, which means that contractual governance, as a formal way of governance, can better regulate the behavior of alliance members when embedded in social networks. Lorenz (1999) believes that through the control of contracts and other contracts, mutual trust can be promoted. Contract can increase trust between partners, even if the participants are very close, it can also promote the accumulation of trust between the two sides. According to Cohen-charash and Spector's (2001) organizational justice framework of "environment and personal factors fairness perception attitude and behavior", individuals will have a sense of fairness (or unfairness) under external stimulation. This sense of fairness (or unfairness) will further affect the attitude and behavior of members. The existing literature has studied the relationship between contractual governance and alliance stability, but no relevant research has been found to study the relationship between contractual governance as a moderating variable and the stability of strategic alliance. This paper studies that contractual governance as a moderating variable will enhance the impact of corporate executives' social relations on opportunistic behavior, thus affecting the stability of strategic alliance.

(7) Contract governance reverses the U-shaped regulation of the impact of corporate executives' social relations on trust, it shows that in the strategic alliance with poor social relations of senior managers, effective contract is the necessary condition to ensure cooperation. Making a contract is helpful to establish a preliminary trust relationship in the environment of poor social relations among senior executives, so as to promote the development of social relations among senior executives and further improve the level of trust among partners; However, when the social relationship among the members of the alliance is high, too many contracts will produce a negative signal of "distrust" and reduce the impact of the social relationship on trust. This is different from Lorenz's (1999) point of view. He believes that through the control of contracts and other contracts, mutual trust can be promoted. This is similar to the point of view which is proposed by Faem (2008). He studies the direct relationship between contract and trust and points out that contracts trigger different types of trust dynamics (negative and positive) in the alliance. Excessive contracts will reduce the trust of partners, and appropriate contracts can have a positive impact on trust (Faems D 2008).

\section{Research Conclusion}

In recent years, the market competition mode is becoming more and more diversified and complex, which makes it difficult for enterprises to survive alone in the current fierce market competition, so strategic alliance, a new modern organizational form, emerges as the times require. Through strategic alliance, member enterprises can share R \& D achievements, reduce production and operation costs, and obtain more resources. In theory, the conclusion of strategic alliance is conducive to the development of enterprises, but in practice, many strategic alliances fail. Therefore, strategic alliance has gradually become the focus of scholars. In this study, 50 enterprises in the strategic alliance were investigated. SPSS21.0 and AMOS24.0 software were used to test the reliability and validity of the scale. The data obtained were used to verify the research hypothesis, and the following results were obtained:

(1) At present, in many parts of the world, especially in China, "relationship culture" is one of the most important social cultures, and the business activities of enterprises will be affected by the social relations of executives to varying degrees. We subconsciously think that the stability of the strategic alliance will also be affected by the social relations of the enterprise executives. However, through the data analysis, we find that the hypothesis of "the social relations of the enterprise executives positively affect the stability of the alliance" is not true. The analysis results show that the social relations of the enterprise executives have no direct impact on the stability of the alliance. There is no direct relationship between senior managers' social relations and alliance stability, but it needs to affect the alliance stability by influencing the intermediate variables.

(2) Corporate executives' social relations negatively affect opportunistic behavior. According to the "broker hypothesis", in economic activities, people who participate in business activities always hope that they can get the maximum profit with the minimum effort. This phenomenon is more likely to happen in strategic alliances. If one 
enterprise in the alliance tries to acquire the technology of other enterprises and share the resources invested but is not willing to invest too much strength in the alliance, and then opportunism happens. The stronger executive social relationship in alliance enterprises will reduce the information asymmetry among alliance members, and the better social relationship will promote the strategic decision-making of each enterprise's executives to focus on the collective interests and common goals of the whole alliance, thus reducing opportunistic behavior.

(3) Opportunistic behavior negatively affects the stability of alliance. Opportunistic behavior will lead to serious information asymmetry among alliance members. In the short term, the input of alliance members is not in direct proportion to the income. In the long term, members are suspicious of each other. The alliance strategy formulated is more inclined to self-protection or self-profit, which ultimately makes the existence of the alliance meaningless and leads to failure.

(4) Corporate executives' social relations will positively affect the trust between partners. Trust is a kind of psychological informal recognition relationship. Although the trust relationship is not restricted by law, it has a great impact on the operation and management of enterprises. A good social relationship between executives can effectively increase the formal and informal communication and interaction between executives of different enterprises, deepen the understanding of both sides, and promote the cooperation in business activities of both sides, so as to continuously build the common interests of both enterprises. At the same time, a good social relationship between senior executives will help to reduce the information asymmetry of alliance enterprises and help the managers of both sides to understand each other. These will be conducive to the establishment of trust among the alliance partners.

(5) Trust among alliance partners has a positive impact on alliance stability. Trust is an important factor affecting the stability of the alliance. The members of the alliance have a high degree of trust, which is more conducive to the formulation and completion of the strategic objectives of the alliance. High trust of alliance members is conducive to the rational use of enterprise resources and the stable and healthy development of the alliance. At the same time, high trust can form a kind of recessive contract among alliance members, reduce information asymmetry, promote alliance members to contribute their own strength, and contribute to the stable development of the alliance.

(6) Contractual governance enhances the impact of corporate executives' social relations on opportunistic behavior. Because of the "broker" hypothesis, people are the main body of economic activities in pursuit of the maximization of economic interests. Members of the strategic alliance are no exception, egoism, information asymmetry and other reasons will lead to opportunistic behavior. Although executive social relations can reduce the possibility of opportunistic behavior, when choosing opportunistic behavior can bring enough benefits to themselves, cooperative members will choose opportunistic behavior. Contract governance, as a formal way of governance, clearly points out the penalty measures for breach of contract, which can better moderate the behavior of partners when embedded in the social relationship network, avoid the possibility that partners choose opportunistic behavior to give up the possibility of maintaining the relationship between the two parties in the face of the temptation of great interests.

(7) The stable development of strategic alliance cannot be separated from the binding governance of contract to alliance members. When the trust degree among the alliance partners is low, it is necessary to make appropriate contracts to restrict the behavior of members, regulate business activities, coordinate and solve existing and potential conflicts, and protect the rights and interests of alliance members. Therefore, when the social relationship of senior managers is general and the trust degree is poor, contractual governance promotes the positive influence of social relationship of senior managers on trust. This kind of situation often occurs in the initial stage of the establishment of strategic alliance, which needs to develop necessary contracts to stabilize the alliance. When the corporate executives have a good social relationship and a high degree of trust, more contracts will give the partners a sense of lack confidence, and form a rebellious psychology in cooperation, which is not conducive to the establishment of a good partnership and weakens the impact of the corporate executives' Social relationship on the trust between partners.

\section{Reference}

Barney J B, Hansen M H. (1994). Trustworthiness as a Source of Competitive Advantage. Strategic Management Journal, 15: 175-190.

Barney J B, Hansen M H. (1994). Trustworthiness as a source of competitive advantage. Strategic Management Journal, 15: 175-190.

Chen J H, Zhang S J, Huang Y. (2010). Research on stability of competitive strategic alliance by analytic hierarchy process. Creativity \& Innovation Management, (17): 631-635.

Cai Qing-feng, TIAN Lin, Guo Jun-feng. (2017). The Influence of Private Entrepreneurs and Cross-regional M\&As - Empirical Findings Based on the Political Connection Level of Actual Controllers of Enterprises within the SME Board. China Industrial Economics, (3): 158-175.

Crssar A., Rigdon M.(2010). Trust and trustworthiness in networked exchange. Games and Economic Behavior, 


\section{2(2):282-303}

Costa P R D, Junior S S B, Porto G S, et al. (2018). Relational capability and strategic alliance portfolio configuration. International Journal of Emerging Markets, 13(5):1026-1049.

Cui L, Hu L Y. (2011). Research on stability of technology innovation alliance based on the safeguard against opportunism. Journal of International Business Studies, (18): 1003-1008.

Cullen J B, Johnson J L, Sakano T.(2000). Success through commitment and trust: The soft side of strategic alliance management. Journal of World Business, 35(3): 223-240.

Cohen-charash Y, Spector P E. (2001). The Role of Justice in Organizations: A Meta-Analysis. Organizational Behavior \& Human Decision Processes, 86(2):278-321.

Draulans J, Deman A P, Volberda H W. (2003). Building alliance capability: Management techniques for superior alliance performance. Long Range Planning, 36(2): 151-166.

Duysters G, Lemmens C. (2003). Alliance group formation: Enabling and constraining effects of embeddedness and social capital in strategic technology alliance networks. International Studies of Management \& Organization, 33(2): 49-68.

Das T K, Teng B S. (2000). A resource-based theory of strategic alliances. Journal of Management, 26(1): 31-61.

Faems D, Janssens M, Madhok A, et al. (2008). Toward an integrative perspective on alliance governance: Connecting contract design, trust dynamics, and contract application. Academy of Management Journal, 51(6): 1053-1078.

Granovetter M S. (1973). The strength of weak ties. American Journal of Sociology, 78(6): 1360-1380.

Ge Zehui, Li Qian, Dai Shufen. (2017). An Analysis of Strategic Commitment in Firms' Innovation Alliances under Cost Uncertainty. Operations Research and Management Science, 26(8): 167-173.

Ganesan S. (1994). Determinants of long-term orientation in buyer-seller relationships. Journal of Marketing, 58(2): 1-19.

Hamel G. (1991). Competition for competence and interpartner learning within international strategic alliances. Strategic Management Journal, 12(S1): 83-103.

Huang Y F, Ye W L, Zhou F F. (2013). Research on the profit distribution of logistics company strategic alliance based on shapley value. Advanced Materials Research, 76: 205-209.

Jorde T M, Teece, David J. (1990). Innovation and Cooperation: Implications for Competition and Antitrust. Journal of Economic Perspectives, 4(3):75-96.

Li D, Eden L, Ireland M A H D. (2008). Friends, acquaintances, or strangers? Partner selection in R \& D alliances. The Academy of Management Journal, 51(2): 315-334.

Liu Y, Li Y, Lei T, et al. (2008). Relationship Stability, Trust and Relational Risk in Marketing Channels: Evidence from China. Industrial Marketing Management, 37(4): 432-446.

Liu Yi, Tao Lei. (2007). A Study on The Interrelationship Between a Retailer's Trust in Its Supplier, Use of Control Mechanism and Relational Value Creation. Journal OF Industrial Engineering and Engineering Management, (1): 61-66.

Lorenz, E. (1999). Trust, contract and economic cooperation. Cambridge Journal of Economics, 23(3): 301-315.

Niedergassel B, Leker J. (2011). Different dimensions of knowledge in cooperative R\&D projects of university scientists. Technovation, 31(4):0-150.

Nunnally J C. (1978). Psychometric theory. American Educational Research Journal, 5(3): 83-87.

Park S H, Ungson G R. (1997). The effect of national culture, organizational complementarity, and economic motivation on joint venture dissolution. Academy of Management Journal, 40(2): 279-307.

Qiao Kun, Xu Huali, Wang Dafei. (2013). Relationship between TMT Social Capital and Financial Performance Based on the Complex Network Community Theory. Chinese Journal of Management, 10(11): 1618-1624.

Simonin B L. (2015). Ambiguity and the process of knowledge transfer in strategic alliances. Strategic Management Journal, 20(7): 595-623.

Smith B. (1998). Buyer-seller relationships: bonds, relationship management, and sex-type. Canadian Journal of Administrative Sciences/Revue Canadienne Des Sciences de l'Administration, 15(1): 76-92.

Virginia Fernández-Pérez, Victor J, García-Morales, et al. (2016). Entrepreneurial decision- making, external social networks and strategic flexibility: The role of CEOs' cognition. European Management Journal, 34(3):296-309.

Wuyts S, Geyskens I. (2005). The formation of buyer-supplier relationships: Detailed contract drafting and close partner selection. Journal of Marketing, 69(4): 103-117.

Wu Shaobo, Gu Xin, Peng Shuang. (2009). The Functions of Knowledge Chain's Collaborative Contracts. Journal of Intelligence, 28(5): 107-110.

Wallenburg C M, Schaffler T. (2014). The interplay of relational governance and formal control in horizontal alliances: A social contract perspective. Journal of Supply Chain Management, 50(2): 41-58.

Wathne K H, Heide J B. (2000). Opportunism in interfirm relationships: Forms, outcomes, and solutions. Journal of Marketing, 64(4): 36-51. 
Yang Jun, Zhang Yuli, Yang Xiaofei, Zhao Ying. (2009). Strength of Ties, Network Resources and New Venture Performance. Nankai Business Review, 12(4): 44-54.

Yang K, Zhu J J, Santoro M D. (2017). Inter-firm managerial social ties and strategic alliances formation: A multiplexity perspective. Social Science Electronic Publishing, (1): 10-151.

Yang Guang. (2009). A Study on The Business Friendship of Senior Managers and The Stability of Strategic Alliance. Science of Science and Management of S.\&.T, 30(2): 197-199.

ZHANG Q, CAO Z. (2004). Research on Risk Prevention and Pre-control for Dynamic Alliance of Enterprises. Policy-making Reference, 3.

Zhu Shaoying, Qi Ershi. (2016). An Empirical Study of Factors Influencing Relational Quality of ProductionEducation-Research Strategic Alliance. Science \& Technology Progress and Policy, 33(3): 12-17. 